\title{
SISTEM PAKAR DIAGNOSA PENYAKIT ALERGI PADA ANAK BERBASIS WEB DENGAN METODE FORWARD CHAINING DI KOTA BATAM
}

\author{
Nanda Jarti ${ }^{1}$, Roden Trisno ${ }^{2}$ \\ ${ }^{12}$ Fakultas Teknik Universitas Putera Batam \\ email : nandaluthan@gmail.com \\ Submitted: 16-03-2017, Reviewed: 17 -03- 2017, Accepted 18-03-2017 \\ http://dx.doi.org/10.22202/jei.2017.v3i2.2245
}

\begin{abstract}
Abstrak
Sistem pakar merupakan sistem berbasis komputer yang menggunakan pengetahuan, fakta, dan teknik penalaran untuk memecahkan masalah yang hanya dapat dipecahkan oleh seorang pakar. Alergi merupakan respon abnormal dari sistem kekebalan tubuh. Orang yang mengalami alergi memiliki sistem kekebalan tubuh yang bereaksi terhadap suatu zat yang biasanya tidak berbahaya di lingkungan. Pembatasan pada penelitian ini terdapat empat penyebab alergi yaitu, alergi makanan laut, alergi debu, alergi susu sapi, dan alergi hewan peliharaan. Dalam perancangan sistem pakar ini merupakan sistem yang digunakan untuk mendiagnosa penyakit alergi pada anak. Proses diagnosa dimulai dengan cara user menjawab pertanyaan-pertanyaan berupa gejala yang diderita oleh user. Metode inferensi yang digunakan adalah runut maju (Forward chaining). forward chaining merupakan teknik pencarian yang dimulai dengan fakta-fakta yang diketahui kemudian dicocokkan menggunakan rule IF-Then. Sistem pakar ini berbasis web sehingga dapat diakses kapanpun dan di manapun oleh user selama mereka terhubung dengan internet dan sistem ini dibangun dengan menggunakan bahasa pemrograman php, database MySQL, dan prosesnya menggunakan adobe dreamweaver CS6. Kesimpulan yang dapat dari hasil penelitian ini antara lain aplikasi sistem pakar yang dirancang mampu mendiagnosa penyakit alergi pada anak berdasarkan gejala-gejala yang diinput oleh user.
\end{abstract}

Kata Kunci : Sistem Pakar, Alergi, Php, MySQL, dan Forward Chainin

\section{PENDAHULUAN}

Alergi dikatakan respon abnormal dari sistem kekebalan tubuh. Orang yang memiliki alergi memiliki sistem kekebalan tubuh yang bereaksi terhadap suatu zat biasanya tidak berbahaya di lingkungan. Biasa alergi disebabkan makan seafood, bulu hewan, debu, dan lain-lain. Gejala-gejala umum dari suatu reaksi alergi terhadap kulit seperti gatal, mata berair, bersin, hidung beringus, merasa lelah atau sakit, dan hives (gatal-gatal dengan bercak merah). Ada juga gejala-gejala alergi menyebabkan reaksi alergi seluruh tubuh seperti gatal-gatal di seluruh badan (bukan hanya di daerah terbuka) , sesak nafas, suara serak, kesemutan di tangan,kaki, bibir, atau kulit kepala. Bagi sebagian orang, hewan peliharaan alergi mungkin menjadi penyebab utama peradangan dan kontraksi dari saluran udara paru-paru (asma), mengakibatkan mengi, sesak napas dan kesulitan bernapas lainnya. Binatang berbulu yang dapat menjadi sumber alergi antara lain kucing, anjing, tikus, dan kuda. Meskipun alergi hewan peliharaan menjadi masalah rumah tangga bisa juga mempengaruhi orang-orang bekerja dengan binatang di pertanian, laboratorium atau di kebun binatang. Gejalagejala yang disebabkan oleh hewan peliharan antara lain bersin, pilek, gatal, merah atau mata berair, hidung, hidung gatal, langitlangit mulut atau tenggorokan, batuk, sering 
terbangun dan mata bengkak. Ada juga hewan peliharaan menyebabkan asma, akan muncul gejala seperti kesulitan bernapas, dada sesak atau sakit, suara mengi saat menghembuskan napas, sulit tidur disebabkan oleh sesak napas, batuk atau mengi, serangan batuk atau mengi yang diperburuk oleh virus pernapasan seperti pilek atau flu. Gejala-gejala yang ada pada alergi sulit memprediksi apakah alergi itu disebabkan oleh makanan, hewan peliharaan, debu, dan lain-lain. Oleh sebab itu banyak orang belum mengetahui berbahayanya alergi itu dan mengetahui cara mencegah dan mengobati alergi itu. Masih belum banyak orang mengetahui tentang sistem pakar mendiagnosa penyakit pada anak di kota batam.

Sistem pakar dikatakan sistem mengadopsikan cara kerja atau pengetahuan manusia ke komputer yang dirancang untuk memodelkan kemampuan masalah seperti seorang pakar. Dengan sistem pakar ini, orang dapat menyelesaikan masalah atau hanya sekedar mencari suatu informasi berkualitas yang sebenarnya hanya dapat diperoleh dengan bantuan para ahli di bidangnya. Sistem pakar juga dapat membantu aktivitas para pakar sebagai asisten yang berpengalaman dan mempunyai asisten yang berpengalaman dan pengetahuan yang di butuhkan. Sistem pakar ini juga dapat membantu aktivitas di bidang kedokteran. Sistem pakar dibidang kedokteran seperti membantu kedokteran untuk menganalisa penyakit-penyakit tertentu dengan mengetahui gejala-gejala pasien untuk mendeteksi penyakit-penyakit yang sedang dialami oleh pasien. Sistem pakar juga memiliki metode-metode salah satu adalah Forward chaining. Metode forward chaining dikatakan metode inferensi yang melakukan penalaran dari suatu masalah kepada solusinya. Oleh sebab itu metode forward chaining mempermudahkan para pakar menyelesaikan suatu masalah di bidang-bidang tertentu. Adapun perumusan masalahnya adalah: 1)Bagaimana analisis sistem pakar diagnosa penyakit alergi pada anak dengan metode forward chaining di kota batam. 2)Bagaimana merancang sistem pakar dengan menggunakan metode forward chaining berbasis web. 3)Bagaimana implementasi sistem pakar dengan mengguna kan bahasa pemograman berbasis web ?Adapun tujuan penelitian ini adalah: 1)untuk mengetahui sistem pakar diagnosa penyakit alergi pada anak dengan metode forward chaining di kota batam. 2)Merancang sebuah sistem pakar dengan menggunakan metode forward chaining berbasis web untuk mendiagnosa penyakit alergi pada anak lebih akurat dan cepat. 3)Dengan bahasa pemograman berbasis web maka mempermudah seseorang mencari informasi atau data-data tentang penyakit alergi serta memberi keterangan cara mencegah alergi pada anak.

\section{METODE PENELITIAN}

1. Mengidentifikasi Masalah

Pada tahap ini untuk menentukan masalah-masalah yang terdapat pada penelitian tersebut yang berjudul " sistem pakar diagnosa penyakit alergi pada anak berbasis web dengan menggunakan metode forward chaining". Untuk mengetahui masalah-masalah yang ada pada penelitian tersebut

2. Pengumpulan Data

Setelah mengidentifikasi masalah, tahap selanjutnya adalah pengumpulan data. Pengumpulan data-data tersebut dari buku dan jurnal yang berhubungan dengan perancangan Sistem, serta datadata penyakit alergi. Dalam penelitian ini tahap pengumpulan data dilakukakan beberapa cara yaitu :

A. Wawancara

Penelitian ini mendapatkan datadata penyakit dengan melalui wawancara langsung pada dokter di dinas kesehatan kota Batam puskesmas sei panas bengkong

B. Studi Pustaka

Pada penelitian juga menggunakan teknik pengumpulan data studi 


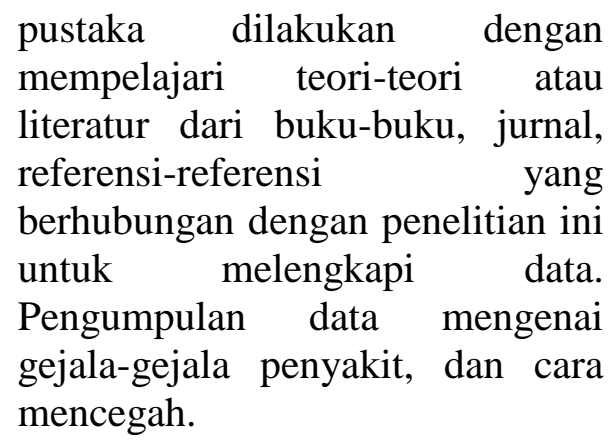

3. Analisis Data

Setelah pengumpulan data, tahap selanjutnya adalah Analisis Data. Data dan informasi yang dikumpulkan akan digunakan untuk mendukung penelitian, data tersebut bias diperoleh melalui wawancara langsung dengan dokter tentang gejala-gejala yang ada pada penyakit alergi pada anak.

4. Mengolah data dengan Metode forward chaining

Pada tahap ini mendapatkan data-data dari wawancara dari dokter tentangtentang gejala penyakit alergi dan cara mencegah penyakit alergi, dan mengolah data dengan menggunakan metode forward chaining untuk mempermudah penelitian ini.

5. Perancangan Sistem

Tahap selanjutnya adalah perancangan sistem. Peracangan sistem ini untuk mendiagnosa penyakit alergi pada anak berbasis web. Perancangan dari model sistem, perancangan sistem input dan merancang rule-rule yang akan digunakan dalam mendiagnosa penyakit alergi pada anak berbasis web berdasarkan data yang ada, merancang UML (Unified Modeling Language) dan merancang prototype.

6. Pengujian Sistem

Pada tahap ini adalah pengujian sistem dilakukan dalam perancangan sistem pakar untuk mendiagnosa penyakit alergi pada anak. Sistem yang di uji dengan prosedur-prosedur untuk melakukan pencocokan rule. Rule yang akan dicocokkan adalah fakta yang ada dengan data yang ada di knowledge base.

7. Implementasi Sistem
Setelah perancangan sistem, diharapkan sistem tersebut mampu memecahkan masalah tentang penyakit alegi pada anak dan memudahkan user mencari informasi dan data tentang penyakit alergi tersebut.

\section{Operasional Variabel}

Menurut Zainal A. Hasibuan (2007:130) Variabel adalah sesuatu yang akan menjadi objek atau sering juga sebagai faktor yang berperan dalam peristiwa atau gejala yang akan diteliti.

Ada beberapa variabel-variabel yang berkaitan dengan penelitian ini sebagai berikut :

Tabel 1 Variabel Alergi Makanan Laut

\begin{tabular}{|c|c|}
\hline Variabel & Indikator \\
\hline \multirow{2}{*}{$\begin{array}{c}\text { Alergi } \\
\text { Makanan } \\
\text { Laut }\end{array}$} & $\begin{array}{l}\text { Gejala-Gejala : } \\
\text { - Kulit gatal-gatal } \\
\text { - } \text { Bengkak (pada bibir, } \\
\text { - } \text { wajah, lidah dan leher) } \\
\text { - } \text { Bersin } \\
\text { - Kidung tersumbat } \\
\text { - Kesulitan bernapas } \\
\text { Kesemutan dimulut }\end{array}$ \\
\hline & $\begin{array}{l}\text { Cara mencegah : } \\
\text { - Cara terbaik untuk } \\
\text { mencegah terjadinya } \\
\text { reaksi alergi di masa } \\
\text { akan datang adalah } \\
\text { dengan menghindari } \\
\text { makanan yang } \\
\text { penyebab alergi }\end{array}$ \\
\hline
\end{tabular}

Tabel 2 Variabel Alergi Debu

\begin{tabular}{|c|c|}
\hline Variabel & \multicolumn{1}{|c|}{ Indikator } \\
\hline & Gejala-Gejala : \\
& - Bersin \\
Alergi & - Hidung tersumbat \\
Debu & - Hidung berair \\
& - Gatal pada mata \\
& - Matuk \\
& - Bata merah \\
& \\
\hline
\end{tabular}


Penelitian Bidang Komputer Sains dan Pendidikan Informatika V3.i2(60-72)

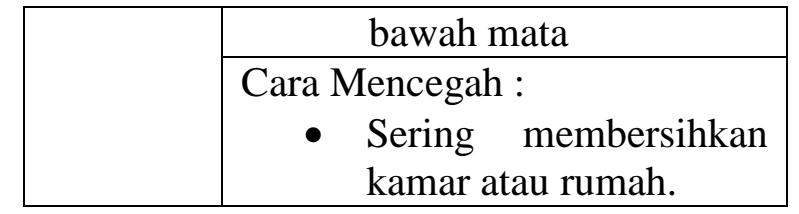

Tabel 3 Variabel Alergi Susu Sapi

\begin{tabular}{|c|c|}
\hline Variabel & Indikator \\
\hline \multirow[t]{2}{*}{$\begin{array}{l}\text { Alergi } \\
\text { Susu } \\
\text { Sapi }\end{array}$} & $\begin{array}{l}\text { Gejala-Gejala : } \\
\text { - Kulit gatal-gatal } \\
\text { - Sakit perut } \\
\text { - Perut kembung } \\
\text { - Mual } \\
\text { - Muntah } \\
\text { - Diare }\end{array}$ \\
\hline & $\begin{array}{l}\text { Cara Mencegah : } \\
\text { - } \\
\text { Menghindari produk } \\
\text { susu yang menyebabkan } \\
\text { alergi }\end{array}$ \\
\hline
\end{tabular}

Tabel 4 Variabel Alergi Hewan Peliharaan

\begin{tabular}{|c|c|}
\hline Variabel & Indikator \\
\hline \multirow[t]{2}{*}{$\begin{array}{c}\text { Alergi } \\
\text { Hewan } \\
\text { Peliharaan }\end{array}$} & $\begin{array}{l}\text { Gejala-Gejala : } \\
\text { - Bersin } \\
\text { - Pilek } \\
\text { - Kulit gatal-gatal } \\
\text { - Mata merah } \\
\text { - Batuk } \\
\text { - Hidung gatal } \\
\text { - Mata bengkak }\end{array}$ \\
\hline & $\begin{array}{l}\text { Cara Mencegah : } \\
\text { - Usaha pengobatan } \\
\text { untuk mengendalikan } \\
\text { alergi adalah dengan } \\
\text { menghindari hewan } \\
\text { peliharaan. }\end{array}$ \\
\hline
\end{tabular}

\section{Perancangan Sistem}

Perancangan sistem adalah mendesain atau merancang suatu sistem, yang berisikan langkah-langkah pengolahan data untuk mendukung suatu sistem. Dalam penelitian ini membahas mengenai perancangan basis pengetahuan (Knowledge Base), UML
(Unified Modeling Language), dan Prototype Web.

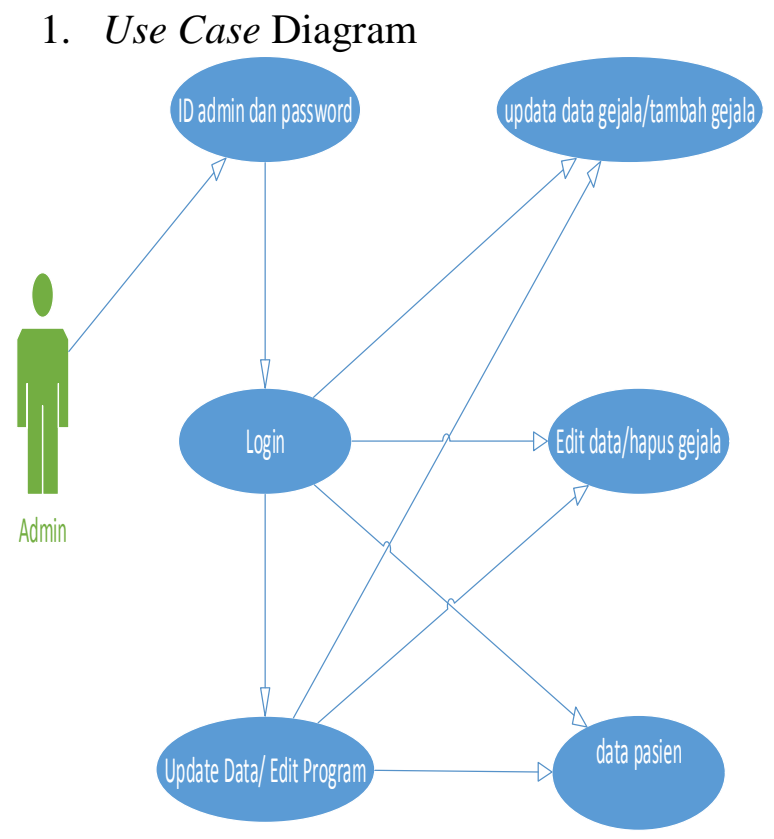

\section{Gambar 1. Use Case Admin}

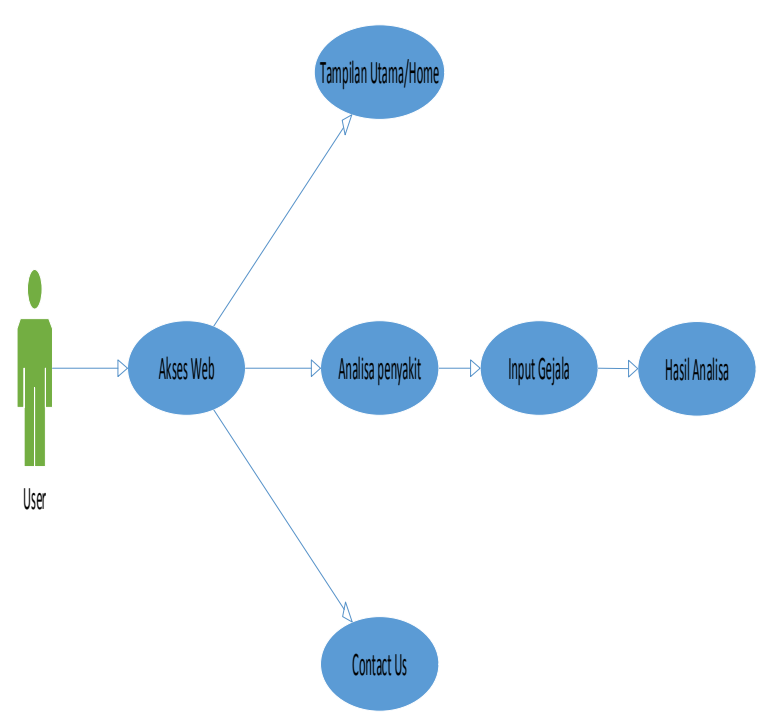

Gambar 2. Use Case User 
Penelitian Bidang Komputer Sains dan Pendidikan Informatika V3.i2(60-72)

2. Activity Diagram

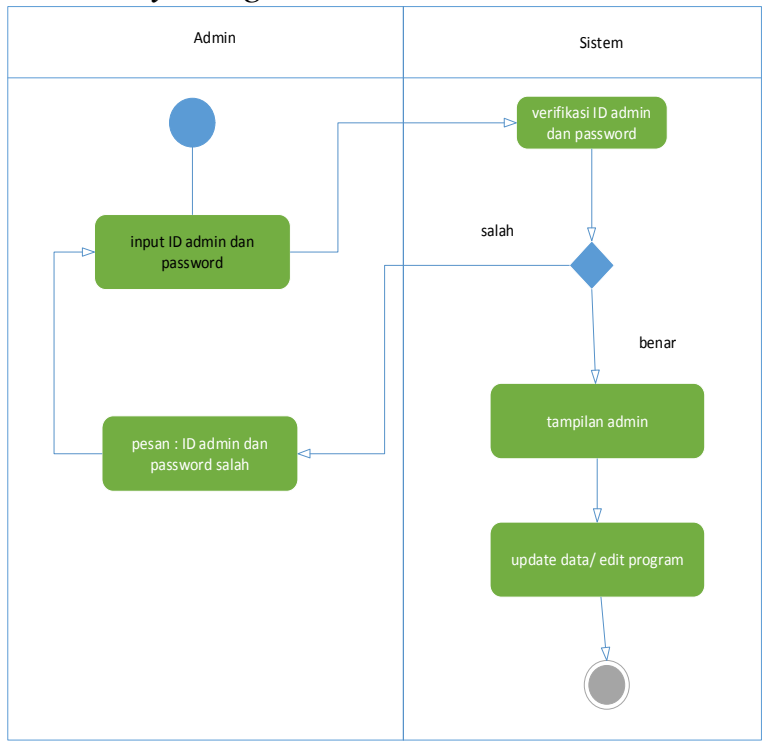

Tabel 5. Activity Diagram Admin

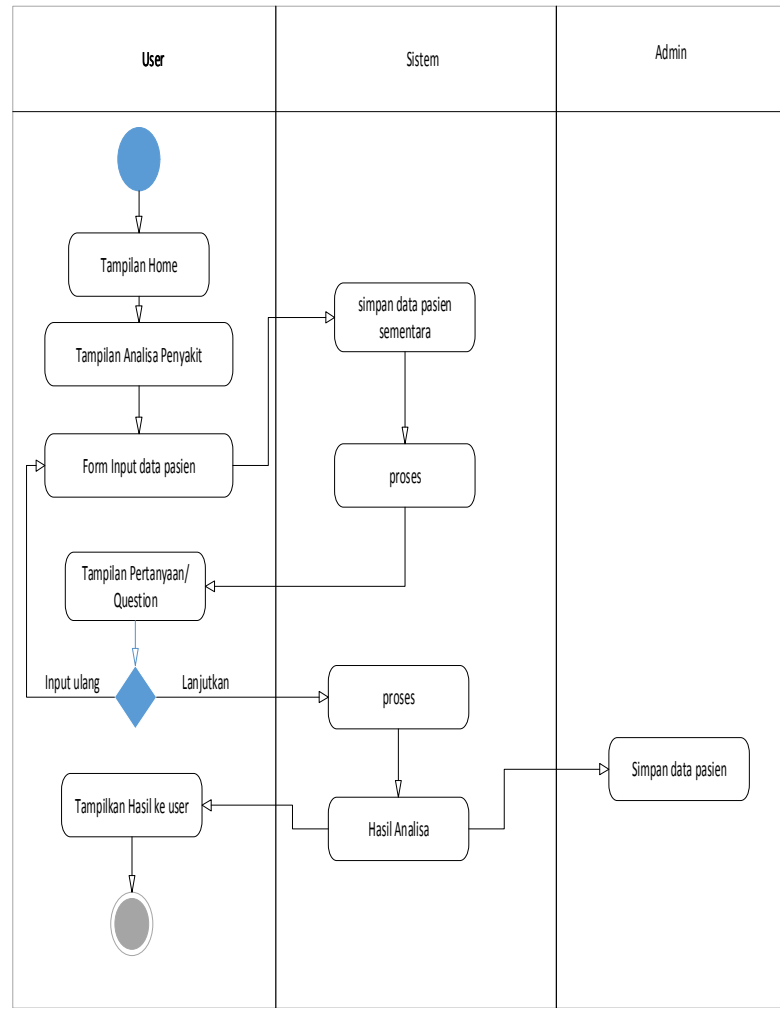

Tabel 6. Activity Diagram User

\section{Class Diagram}

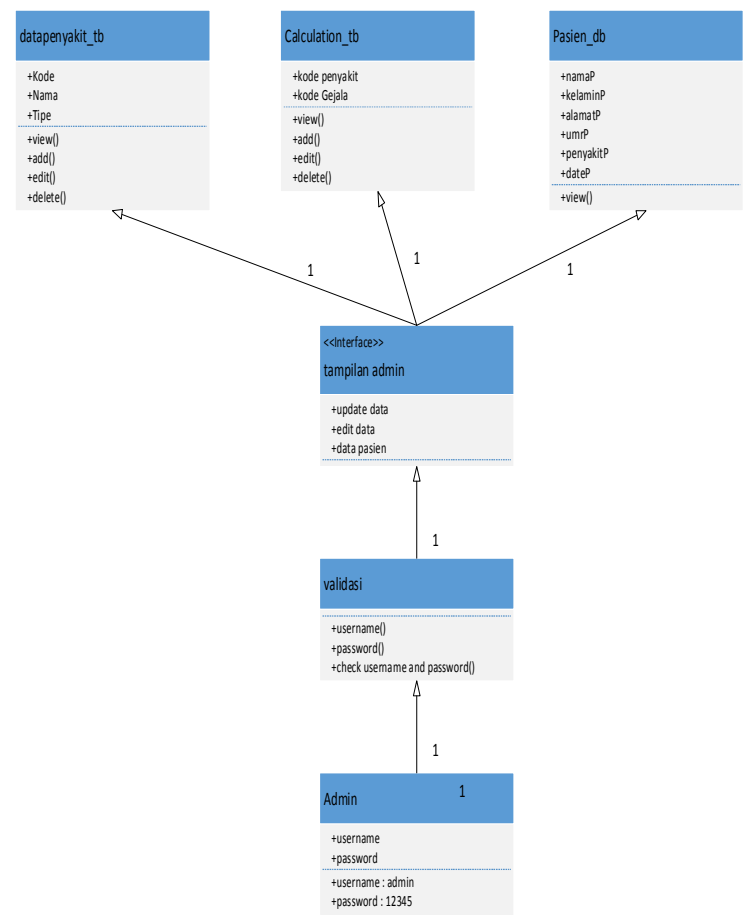

Gambar 3. Class Diagram

4. sequens diagram

Tabel 7. Sequens Diagram Admin

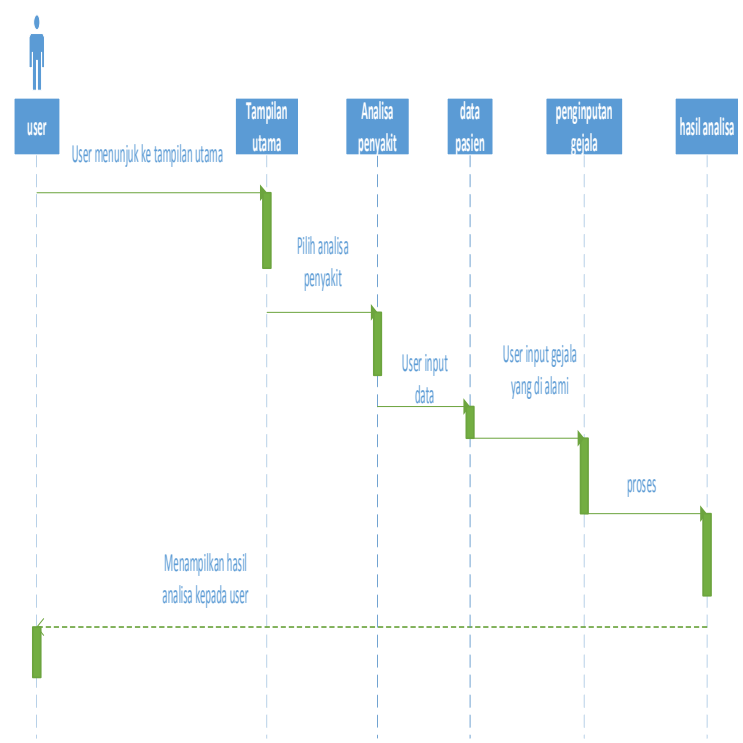


Penelitian Bidang Komputer Sains dan Pendidikan Informatika V3.i2(60-72)

Tabel 7. Sequens Diagram User

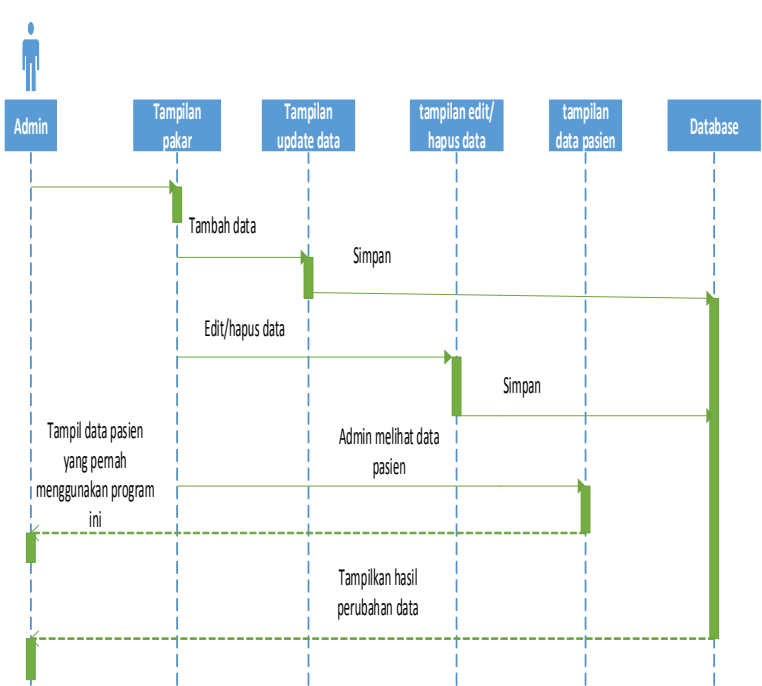

\section{HASIL DAN PEMBAHASAN}

\section{Hasil Penelitian}

\section{A. Tampilan Menu Utama}

Berikut ini adalah tampilan utama sebuah web untuk user. Tampilan tersebut terdapat beberapa features yaitu Login Admin, Analisa penyakit, dan Contact Us. Analisa penyakit adalah features untuk konsultasi penyakit alergi pada anak. Pada menu analisa penyakit terdapat form untuk user masukkan data-data user. Tampilan Home/Utama untuk user dapat dilihat pada gambar di bawah ini :

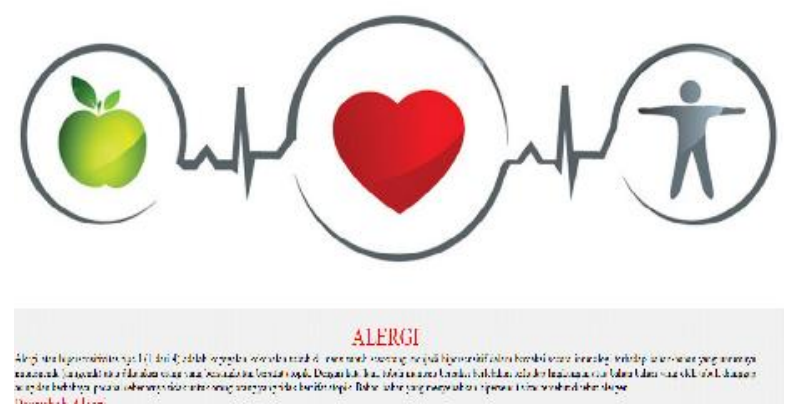

Gambar 4. Menu Utama

\section{B. Tampilan Form Update}

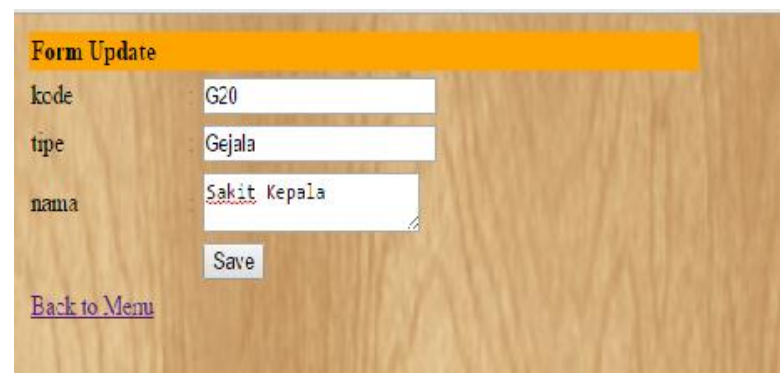

Gambar 5. Form Update

\section{C.Tampilan Edit Data}

\begin{tabular}{|c|c|c|c|c|}
\hline 14 & Gia & 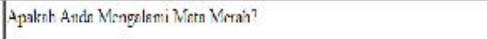 & Grigina & Deats \\
\hline 15 & Git & 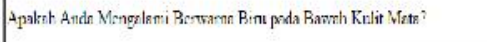 & Grenglo & \begin{tabular}{|l} 
Dietts \\
$\underline{\text { Ejit }}$
\end{tabular} \\
\hline 16 & G.2 & Apalksth Auda Meagalonsi Sakit Perur? & Gevala & 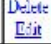 \\
\hline 17 & G.3 & Apalksth Auda Meagglosni Penur kembring? & Gevala & $\begin{array}{c}\text { Deiete } \\
\text { Fäit }\end{array}$ \\
\hline 18 & G:1 & Apalsat Auda Meugalonsi Nua?? & Geglas & $\begin{array}{c}\text { Deitet } \\
\text { Fait }\end{array}$ \\
\hline 19 & Gis & 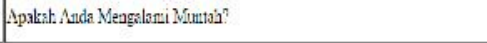 & Gegla & $\begin{array}{c}\text { Detete } \\
\text { Fait }\end{array}$ \\
\hline 20 & G.6 & Apalsat Auda Meugalonsu Dhare? & Gegala & \begin{tabular}{|l|l} 
Delet: \\
Fait
\end{tabular} \\
\hline 2$]$ & (il: & 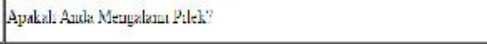 & Gegalix & 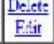 \\
\hline 23 & Gis & 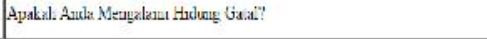 & Gegla & $\frac{1 \text { Dect: }}{\text { Exhit }}$ \\
\hline 23 & Gis & 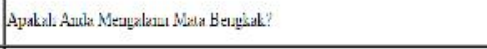 & Gegalix: & $\frac{\text { Decet: }}{\text { Einit }}$ \\
\hline 24 & $\because 1$ & 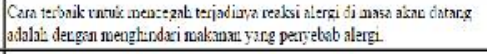 & Suluikis & \begin{tabular}{|l} 
Deiet: \\
Eijit \\
\end{tabular} \\
\hline 25 & $m$ & 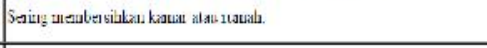 & Suluivins & $\frac{\text { DNirts }}{\text { Exit }}$ \\
\hline 26 & $\infty$ & Menahindari produle susu vang nearebablen alezgi & Solution & $\frac{\text { Drits }}{\text { Eilal }}$ \\
\hline & N4 & 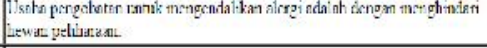 & Solution & $\frac{\text { DNints }}{\text { Eijt }}$ \\
\hline 28 & 00 & Salkit Kepalas & Geiala & $\frac{\text { Dricts }}{\text { Eist }}$ \\
\hline
\end{tabular}

Gambar 6. Tampilan Edit Data

d.Tampilan data pasien

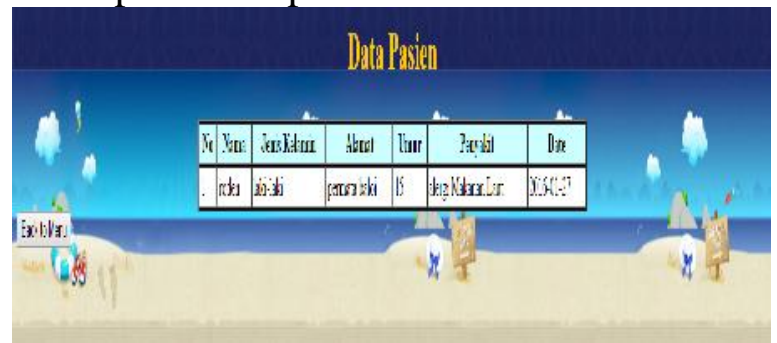

Gambar 7. Tampil Data Pasien 
e.hasil tambah data baru

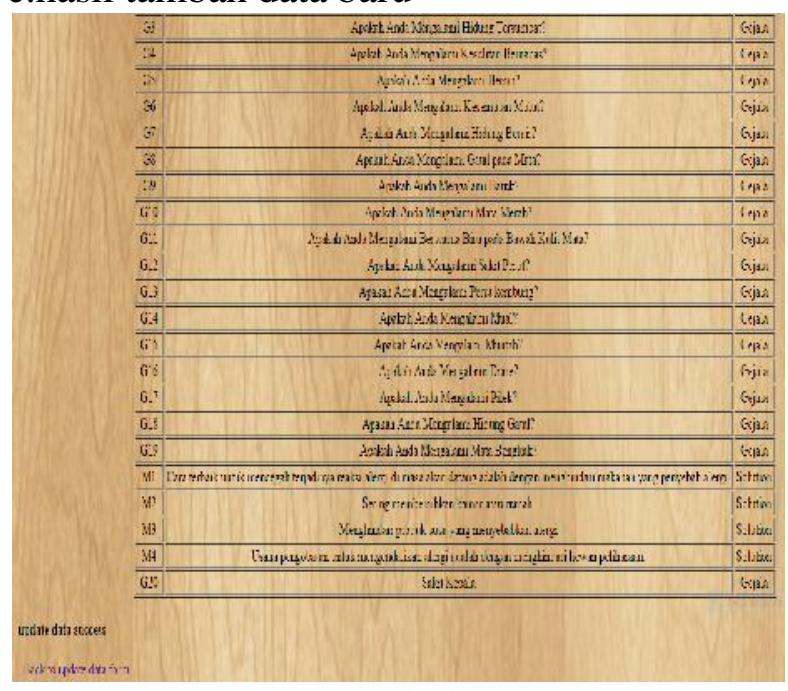

Gambar 8. Tambah Data Baru

f. contact us

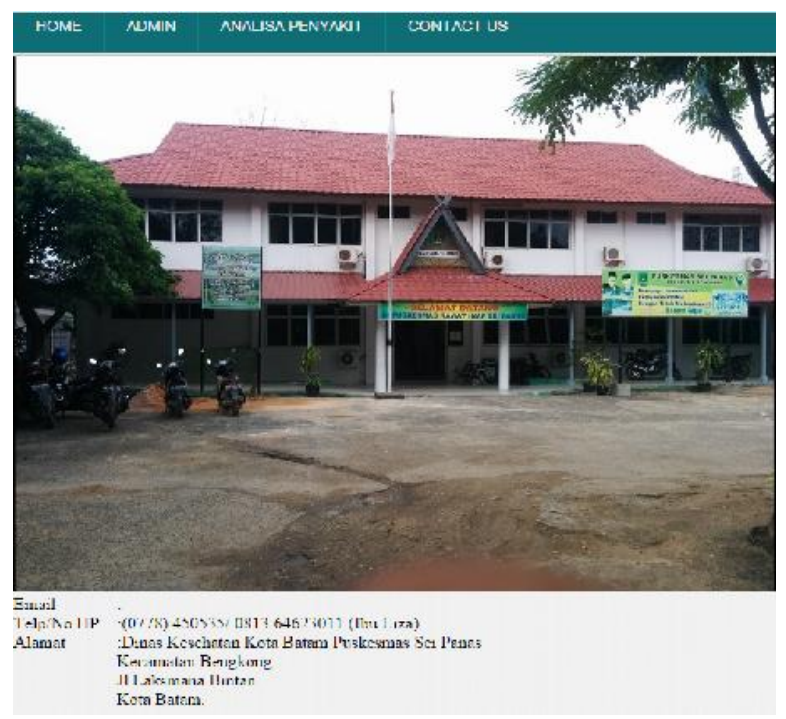

Gambar 9. Contact Us

\section{Pembahasan}

pada penelitian ini akan membahas tentang sistem pakar yang dirancang arsitektur sistem pakar. Perancangan arsitektur tersebut mempunyai Explanation Facilities (EF), User Interface (UI), Inferensi Engine (IE), Knowledge Base, dan database. Perancangan arsitektur bisa dilihat pada gambar dibawah 4.15 ini.

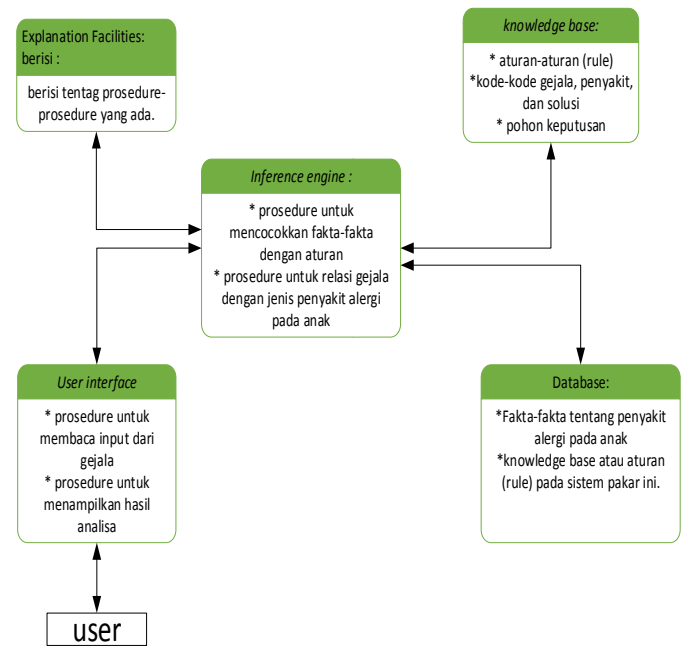

\section{Gambar 10: Arsitektur Sistem Pakar Penyakit Alergi pada Anak}

Pada gambar 4.15 adalah komponenkomponen yang ada pada sistem pakar Penyakit Alergi pada anak. Komponenkomponen Arsitektur Sistem pakar adalah sebagai berikut :

1. User, yaitu orang atau pasien yang akan menggunakan aplikasi sistem pakar ini, pada tahap ini user akan menginputkan data sendiri user atau pasien, setelah menginputkan data sendiri akan dilanjutkan dengan menginputkan pertanyaan-pertanyaan yang berupa gejala-gejala yang dialami oleh user.

2. User Interface, merupakan procedur untuk membaca fakta-fakta berupa gejala-gejala yang dialami oleh user, selain itu user interface ini juga digunakan untuk menampilkan hasil analisa berupa penyakit yang diderita user serta memberikan solusi.

3. Explaning facilities, berisi procedurprocedur yang ada seperti Contact Us.

4. Inference Engine (Model inferensi), berisi procedur untuk mencocokkan antara fakta-fakta dengan aturan (rule) pada metode forward chaining.

5. Knowledge base (pengetahuan basis) berisi tentang aturan-aturan (rule), kodekode (gejala, penyakit, solusi), dan pohon keputusan. 
Penelitian Bidang Komputer Sains dan Pendidikan Informatika V3.i2(60-72)

6. Database, berisi fakta-fakta tentang penyakit alergi pada anak dan knowledge base atau aturan (Rule) pada sistem pakar ini.

\section{SIMPULAN DAN SARAN}

\section{Kesimpulan}

Berdasarkan penelitian ini aplikasi sistem pakar yang telah dirancang ini dapat beberapa kesimpulan sebagai berikut :

1. Aplikasi sistem pakar yang dirancang mampu mendiagnosa penyakit pada anak berdasarkan gejala-gejala yang di input oleh user.

2. Aplikasi sistem pakar dirancang dengan menggunakan metode forward chaining berbasis web maka user dapat konsultasi penyakit di manapun dan kapanpun.

3. Aplikasi sistem pakar mempermudahkan user mendapatkan untuk mendapatkan data-data atau informasi yang diperlukan oleh user tentang penyakit alergi pada anak.

\section{Saran}

Dalam penelitian ini aplikasi sistem pakar ini terdapat beberapa saran yaitu :

1. Aplikasi sistem pakar ini dapat dikembangkan lagi, sehingga dapat menganalisis lebih banyak penyakit alergi pada anak.

2. Aplikasi sistem pakar ini dapat dikembangkan dengan mempertajam hasil diagnose sehingga data yang didapatkan lebih akurat dan lebih baik.

3. Aplikasi sistem pakar ini bisa dikembangkan lagi terutama pada tampilan UI (User interface) dan diharapakan sistem pakar ini dapat dikembangkan dengan menggunakan metode seperti backward chaining atau kedua-duanya untuk memberikan nilai kepastian terhadapat hasil dari diagnose.

\section{DAFTAR PUSTAKA}

Rohman, Feri Fahru, dan Fauzijah Ami, (2008). Rancang Bangun Aplikasi

Sistem Pakar Untuk Menentukan Jenis Gangguan Perkembangan Pada Anak, Media Informatika. 1 (6): 3.

Putri, Prista Amanda, dan Mustafidah

Hindayati, (2011). Sistem Pakar Untuk Mendiagnosa Penyakit Hati

Menggunakan Metode Forward Chaining ( Expert System Diagnosing

Liver Disease Using Forward

Chaining), Juita. 4 (1): 145.

Hassul, Kurniawati, dan Fatimah, (2014).

Dampak Alergi Makanan Pada Prestasi

Belajar Anak Usia Sekolah, Journal of

Pediatric Nursing. 1 (1): 1.

Rohman, Feri Fahru, dan Fauzijah Ami, (2008). Rancang Bangun Aplikasi

Sistem Pakar Untuk Menentukan Jenis Gangguan Perkembangan Pada Anak, Media Informatika. 1 (6): 6.

Tanjung, Hakim Dahriani (2015). Jaringan

Saraf Tiruan Dengan Backpropagation

Untuk Memprediksi Penyakit Asma,

Citec journal. 1 (2) : 29.

Ginting, Budi S, M.Kom (2014).

Perancangan Sistem Pakar Diagnosa

Kerusakan Blackberry Smartphone

Berbasis Web, Informasi dan

Teknologi Ilmiah (INTI). 2 (3) : 36.

Kusnadi, Adhi (2013). Perancangan Aplikasi

Sistem Pakar untuk Mendiagnosa

Penyakit Pada Manusia, Ultimatics. 1

(4) $: 3$.

Pangerapan, Octavia Ritha (2013). Analisis

Perlakuan Akuntansi Untuk Website

Pada PT. Bank Sulut (Persero)

Manado, Jurnal Emba. 3 (1) : 764.

Aziz, E. F. , Damiri, D. J. , dan Destiani, D.

(2014). Perancangan Sistem Pakar

Diagnosis Penyakit Syaraf Pada Wajah

Berbasis Web, Jurnal Algoritma. 1 (11)

$: 2$.

Sulistyorini, Prastuti (2009). Pemodelan

Visual dengan Menggunakan UML

dan Rational Rose, Jurnal Teknologi

Informasi DINAMIK. 1 (14) : 23-24. 
Penelitian Bidang Komputer Sains dan Pendidikan Informatika V3.i2(60-72)

Verina, Wiwi (2015). Penerapan Metode Forward Chaining untuk Mendeteksi Penyakit THT, Jatisi. 2 (1) : 125-126.

Kusrini, S.Kom . (2006). Sistem pakar Teori dan Aplikasi. Edisi 1. ANDI. Yogyakarta.

Rini, Ayu . (2015). Mencegah Alergi Makanan. Edisi 1. PT Elex Media Komputindo. Jakarta.

Peranginangin, Kasiman. (2006). Aplikasi Web dengan PHP dan MySQL. Edisi 1. ANDI. Yogyakarta.
Irianto, Koes. (2015). Memahami Berbagai Macam Penyakit (Penyebab, Gejala, Penularan, Pengobatan, Pemulihan, dan Pencegahan). Edisi 1. ALFABETA, cv. Bandung.

Sutojo, T, S.Si., M.Kom, Edy Mulyanto, S.Si., M.Kom, dan DR.Vincent Suhartono. (2011). Kecerdasan Buatan. Edisi 1. ANDI. Yogyakarta.

Hasibuan, Zainal A., PhD.(2007). Metodologi Penelitian Pada Bidang Ilmu Komputer Dan Teknologi Informasi. Edisi 1. Depok 